3. Конвенція про боротьбу з незаконними актами, спрямованими проти безпеки цивільної авіації від 23.09.1971 // БД «Законодавство України» / ВР України. URL: https://zakon.rada.gov.ua/laws/show/ 995_165\#Техt (дата звернення:12.04.2021).

4. Повітряний кодекс України: Закон України від 19.05.2011 № 3393-VI // БД «Законодавство України» / ВР України. URL: https://zakon.rada.gov.ua/laws/show/3393-17 (дата звернення: 12.04.2021).

5. Про Державну програму авіаційної безпеки цивільної авіації: Закон України; Програма від 21.03.2017 № 1965-VIII // БД «Законодавство України» / ВР України. URL: https://zakon.rada.gov.ua/laws/show/ 1965-19\#Text 17 (дата звернення: 12.04.2021).

6. Філіппов А.В. Поняття авіаційної безпеки: новели вітчизняного. та міжнародного права, проблеми гармонізації // Юридичний науковий електронний журнал. 3/2018. URL:http://lsej.org.ua/3_2018/70.pdf (дата звернення: 12.04.2021).

7. Кримінальний кодекс України: Закон України від 05.04.2001 № 2341-III // БД «Законодавство України» / Верховна Рада України. URL: https://zakon.rada.gov.ua/laws/show/2341-14 (дата звернення: 12.04.2021).

DOI https://doi.org/10.30525/978-9934-26-074-2-51

\title{
ТИПОЛОГІЗАЦІЯ ЖЕРТВ ЗЛОЧИНІВ: КРИМІНОЛОГІЧНИЙ АНАЛІЗ
}

\author{
Луценко I. Г. \\ кандидат юридичних наук, \\ доцент кафедри кримінального права та кримінології \\ факультету № 6 \\ Харківського начіонального університету внутрішніх справ \\ м. Харків, Украӥна
}

Питання про вивчення жертви злочину на сучасному етапі розвитку суспільних відносин носить досить актуальний характер. Віддаючи належне існуючим фундаментальним науковим дослідженням у зазначеній сфері, сучасним науковцям доводиться стикатися з новими викликами як кримінального світу так і загально цивілізаційних процесів, які породжують, провокують та живлять злочинність, що призводить до збільшення жертв злочинів. Це пов'язано із соціальною природою 
злочинності, яка будучи складовою будь якого суспільства $є$ динамічним i прогресивним явищем. Збільшення і різноманітність кримінальних правопорушень безпосередньо впливає на віктимізацію суспільства, a отже i збільшення детермінант, як групового так і індивідуального характеру, які перетворюють особу (групу осіб) із потенційної в реальну жертву злочину.

Типологія жертв злочинів є важливим і водночас досить складним питанням, оскільки жертвою злочину, особливо в українських реаліях (високий рівень злочинності, корупція, анексія, збройний конфлікт, пандемія COVID-19), може стати будь-яка людина на шляху від народження і до смерті.

Теоретичне значення типології жертв злочинів полягає у визначенні ролі жертви злочину у механізмі злочинної поведінки, а також природи причин і умов, що сприяють виникненню та збільшенню рівня віктимності. Відповіді також потребують питання чому деякі люди частіше стають жертвами злочинів ніж інші і яку роль відіграють відношення між жертвою і злочинцем в генезисі кримінологічних механізмів. У практичній діяльності типологія жертв злочинів необхідна для розробки та впровадження заходів протидії віктимізації, спрямованих на потенційних жертв злочинів, а також для захисту від вторинної вікмізації реальних жертв злочинів.

Німецьким кримінологом Гансом фон Гентінгом, ім'я якого пов'язують зі створенням віктимології, у монографії «Злочинець і його жертва. Дослідження за соціобіологією злочинності» було запропоновано різні типи жертв злочинів: молодь (діти); жінки; люди похилого віку; іммігранти; представники національних меншин; алкоголіки; безробітні; психічно недорозвинені та хворі. Під психологічними типами жертв злочинів цей автор розуміє: 1) так звані «депресійних суб'єктів»; 2) осіб, схильних до неправомірного отримання вигоди; 3) осіб, схильних до надміри кохання; 4) самотніх осіб; 5) осіб, які надміру легко i агресивно проявляють своє незадоволення; 6) осіб, які потрапили у так звані «безвихідні ситуації» [1, с. 386-389]. Безумовно, запропонована типологізація жертв злочинів має важливе значення у часи зародження і становлення віктимології, проте іiі аналіз свідчить про необгрунтованість деяких позицій.

Так, наприклад, серед жертв, що постраждали від вияву кримінальнонасильницької поведінки, жінки становлять $18 \%$, з них $89 \%$ сприяли злочинному посяганню через свою віктимну поведінку. Кількість чоловіків, постраждалих від кримінального насильства, становить $82 \%$, причому поведінка, що сприяла вчиненню насильницького злочину, спостерігалася в 90 \% випадків. Отже, тільки щодо $11 \%$ жінок і $10 \%$ чоловіків, постраждалих від фізичного насильства, було встановлено нейтральну поведінку [2, с. 10]. 
У США ситуація складається наступним чином: чоловіки у 1,5-2 рази частіше, ніж жінки, можуть бути жертвою тяжкого злочину, проте жінки найбільш вірогідно стають жертвами насильства. 31000 американців - 105, а з тієї самої кількості американок - лише 80 щорічно стають жертвами. Чоловіки в 2,5 рази частіше зазнають нападу за обтяжуючих обставин [3, с. 4].

Таким чином, можливість перетворитися на жертву злочину через статеву приналежність безпосередньо залежить від виду злочинних посягань.

Творець віктимології і автор ії назви Бенджамін Мендельсон поділяв типи жертв залежно від критеріїв вини жертви, а саме: 1) жертви, повністю не винні (наприклад, діти); 2) жертви з незначним ступенем ризику (наприклад, жінки, які прийняли рішення про здійснення аборту, внаслідок якого померли); 3) жертви, винні настільки ж, як і злочинець (наприклад, жертви самогубств); 4) жертви, більш винні, ніж злочинець (наприклад, особи, які спровокували злочинця або були надто необережними); 5) жертви, виключно винні у вчиненні злочину (наприклад, така ситуація може мати місце тоді, коли фактичний злочинець діяв у порядку крайньої необхідності); 6) уявна жертва (жертвами $\epsilon$ особи, які страждають від розумових розладів, помилково приписуючи собі якості жертви) [4, с. 45].

Беззаперечна цінність і цієї типологізації, проте вона носить комплексний підхід щодо поділу жертв злочинів і має узагальнений вигляд, оскільки вина жертви злочину на пряму залежить від: вікової віктимності, віктимної патології, рольової (професійної) віктимності, віктимогенної ситуації та інших віктимологічних аспектів.

У свою чергу, польський кримінолог М. Куць пропонує проводити типологізації жертв злочинів за кримінально-правовими та кримінологічним критеріями [5, с. 96]. Таким чином, за кримінально-правовим критерієм типи жертв злочинів можуть бути такими: жертви убивств; жертви згвалтувань; жертви крадіжок, жертви шахрайств i т.д. (в залежності від конкретних складів злочинів, передбачених кримінальним законом) або жертви злочинів про статевої свободи та статевої недоторканості, жертви злочинів проти власності, жертви злочинів проти довкілля (в залежності від розділів Особливої частини Кримінального кодексу України). За кримінологічним критерієм можна виокремити типи жертв злочинів за віком: діти; неповнолітні; особи похилого віку; за статтю: чоловіки, жінки; за видами злочинності: жертви агресивної, корисливої, рецидивної злочинності та інші.

На нашу думку, саме кримінологічний критерій типологізації жертв злочинів носить більш практичне значення, оскільки між діями злочинця і поведінкою жертви існує генетичний зв'язок (до/під час/після вчинення злочину), окрім ситуативного типу жертв (має місце збіг обставин), що дозволяє виділити і дослідити спільні детермінанти між злочинністю 
(особою злочинця) та віктимністю (жертвою злочину) у біологічному, психологічному, соціальному та інших аспектах.

Уваги також заслуговує позиція Д. Рівмана, який пропонує виокремлювати жертв злочинів в залежності від їх активності, оскільки поведінка потенційної жертви досить часто має вирішальне значення у механізмі вчинення злочину, таким чином науковець виділяс: 1) агресивних потерпілих (це потерпілі, поведінка яких полягає у нападі на майбутнього злочинця або інших осіб (т.-зв. агресивні насильники) або у агресії в інших формах, наприклад, у образі, наклепі, знущанні (т.-зв. агресивні провокатори); 2) активних потерпілих (це потерпілі, поведінка яких не пов'язана 3 нападом або поштовхом у формі конфліктного контакту, але спричинення їм шкоди відбувається за їх активного сприяння (свідомі підбурювачі, необережні підбурювачі i т. д.); 3) ініціативних потерпілих (це потерпілі, поведінка яких має позитивний характер, але призводить до спричинення їм шкоди (ініціативні за посадою, ініціативні за соціальним становищем, ініціативні за особистими якостями); 4) пасивних потерпілих (це потерпілі, які не здійснюють опору або протидії злочинцеві у зв'язку 3 різними причинами (наприклад, постійно або тимчасово не здатні до опору); 5) некритичних потерпілих (це потерпілі, які проявляють необачність або невміння правильно оцінювати життєві ситуації (особи 3 низьким освітнім рівнем, особи з низьким інтелектом, неповнолітні, особи похилого віку, психічно хворі); 6) нейтральних потерпілих (це потерпілі, поведінка яких $є$ абсолютно позитивною; вона не була жодним чином негативною і не викликала злочинних діянь; у межах своїх можливостей потерпілий критично сприймав ситуацію) [6, с. 55-56].

Типологізація, запропонована Д. Рівманом розкриває роль жертви злочину у соціально-психологічному аспекті i має практичне у проведенні девіктимізації на індивідуальному рівні.

Проаналізовані нами типологізації жертв злочинів свідчать про різноманітність підходів у дослідженні феномену «жертва злочину», проте зазначені позиції кримінологів лише доповнюють один одного i спрямовані на виявлення потенційних жертв задля профілактичної роботи із ними, усунення детермінант, що сприяють віктимності, а також допомоги реальним жертвам.

Принагідно зауважити, що розробка нових і вдосконалення існуючих типологізацій відбувається за різними критеріями, такими як особистісні якості жертви; характер поведінки жертви; рольовий статус жертви; за характером заподіяної шкоди; за кількістю посягань на жертву впродовж певного періоду часу та інші. Таким чином, всі типологізації об'єднані двоєдиною метою, по-перше, - визначення ролі і значення жертви у механізмі злочинної поведінки i, по-друге, - виявлення детермінант злочинності та протидії ій. 


\title{
Література:
}

1. Von Henting H. The Criminal and His Victim. Studies in the Sociobiology of Crime: monograph. New York: Schocken Books, 1979. 461 c.

2. Кулик О. Г. Злочинність в Україні на початку XXI століття : монографія. Київ: Юрінком Інтер, 2013. 272 с.

3. Демографический профиль жертв пре ступлений. Борьба $c$ преступностью за рубежом. 2014. № 4. С. 3-7.

4. Amin S. M. Ofiara przestępstwa we współczesnych systemach prawnokarnych ze szczególnym uzwględnieniem jurysprudencji Islamu. Toruń: Wydawnictwo Uniwersytetu Mikołaja Kopernika, 1995. 267 c.

5. Kuć M. Wiktymologia. Warszawa: Wydawnictwo C. H. Beck, 2010. $176 \mathrm{c}$.

6. Ривман Д. Криминальная віктимологія. Санкт-Петербург: Питер, 2002. $304 \mathrm{c}$.

DOI https://doi.org/10.30525/978-9934-26-074-2-52

\section{ПРАВОВІ ПІДСТАВИ ДІЙ ПРАЦІВНИКІВ НАЦІОНАЛЬНОЇ ПОЛІЦІЇ ПРИ ВИКОНАННІ ПОЛОЖЕНЬ Ч. 2 СТ. 10 ЗАКОНУ УКРАЇНИ «ПРО ЗАПОБІГАННЯ ТА ПРОТИДІЮ ДОМАШНЬОМУ НАСИЛЬСТВУ»}

\author{
Малиновська Т. М. \\ кандидат юридичних наук, доцент, \\ провідний науковий співробітник \\ Науково-дослідної лабораторії з проблем протидї злочинності \\ Харківського національного університету внутрішніх справ \\ Шорохова Г. М. \\ науковий співробітник \\ Науково-дослідної лабораторії з проблем протидї̈ злочинності \\ Харківського національного університету внутрішніх справ \\ м. Харків, Україна
}

Україна розвивається як демократична, соціальна та правова держава. Конституція України проголосила, що основні права і свободи людини й громадянина є найвищої соціальною цінністю.

Широке розуміння конституційного права на свободу і особисту недоторканність охоплює такі конституційні можливості, як особиста свобода і безпека, недоторканність житла, недоторканність таємниці 